\title{
EFFECT OF AIR FLOW RATES AND MIXING PERIODS ON THE COMPOSTION OF FOOD RESIDUES HESHAM A. FARAG
}

Agricultural Engineering Research Institute ARC, Dokki, Giza

(Manuscript received 9 March 2008)

\section{Abstract}

\begin{abstract}
Food waste and sawdust were used to produce compost using a composting bioreactor system. The moisture content and $\mathrm{C}: \mathrm{N}$ ratio of the initial mixture were adjusted at $60 \%$ and $30: 1$, respectively. Three aeration rates and two mixing periods were used in this experiment. Moisture content, dry matter, $\mathrm{pH}$, total Kjeldahl nitrogen, total carbon, bulk density, total phosphate and total potassium were measured on the initial mixture and at the end of composting process. The temperature changes and $\mathrm{CO}_{2}$ rates were monitored and recorded in all the bioreactors. The results indicated that the maximum temperature ranged from 48 to $52{ }^{\circ} \mathrm{C}$ depending on the aeration rate and mixing period. The maximum temperature that was higher than $50^{\circ} \mathrm{C}$ was found only in bioreactors $C_{1}$ and $C_{2}$ and was maintained for three days. In all reactors the $\mathrm{CO}_{2}$ emission increased and was proportional to the temperature and aeration rates. The relation between temperatures, emissions of carbon dioxide, aeration rates and the mixing period in this study was found to be $(T=20+6.5$ $\left.\mathrm{CO}_{2}+24 \mathrm{~A}-0.01 \mathrm{M}\right)$, $\mathrm{T}$ : the compost temperature $\left({ }^{\circ} \mathrm{C}\right)$, A: the aeration rate $\left(\mathrm{m}^{3} / \mathrm{h}\right), \mathrm{M}$ : mixing period $(\mathrm{h}), \mathrm{CO}_{2}$ : emission of carbon dioxide (\%). An aeration rate of $0.15 \mathrm{~m}^{3} / \mathrm{h}$ and mixing period of $12 \mathrm{~h}$ produced good quality compost in 18 days and saved $50 \%$ of the power consumed in the mixing operation.

Key words: aeration rates, bioreactor, compost, food residues, mixing, waste recycle, $\mathrm{CO}_{2}$, Temperature.
\end{abstract}

\section{INTRODUCTION}

Composting is seen as a mean of turning waste materials into a valuable product that can be recycled back to the soil. It promotes soil fertility, reduces environmental pollution and eliminates weed seed and pathogen viability. The quality of compost is affected by several factors including; $\mathrm{pH}$, temperature, moisture content, availability of micronutrients, $\mathrm{C}: \mathrm{N}$ ratio, bulking density, mixing and oxygen supply.

Polprasert et al. (1994) reported that the composted water hyacinth plants mixed with leaves and pig manure contained $\mathrm{N}, \mathrm{P}^{\prime}$, and $\mathrm{K}$ of about $2.2,1.5$ and $0.8 \%$ respectively. The pile with a $\mathrm{C}: \mathrm{N}$ ratio of $30: 1$ had a higher temperature build - up than that of $25: 1$ during the first few days of composting.

Liang et al. (2003) conducted composting experiments using a 2-factors factorial design with six temperatures $\left(22,29,36,43,50\right.$, and $\left.57{ }^{\circ} \mathrm{C}\right)$ and five 
moisture contents $(30,40,50,60$, and $70 \%)$. The microbial activity was measured as $\mathrm{O}_{2}$ uptake rate $\left(\mathrm{mg} \mathrm{g}^{-1} \mathrm{~h}^{-1}\right)$ using a computer controlled respirometer. In this study, moisture content proved to be a dominant factor impacting aerobic microbial activity of the composting blend. Fifty percent moisture content appeared to be the minimum requirement for obtaining activities greater than $1.0 \mathrm{mg} \mathrm{g}^{-1} \mathrm{~h}^{-1}$ while the range of 60 - $70 \%$ provided maximum activities. Temperature was also documented to be an important factor for biosolids composting. For the main effect of temperature, the magnitude of cumulative $\mathrm{O}_{2}$ uptake was found to be highest at $43^{\circ} \mathrm{C}$.

Alkoaik and Ghaly (2006) performed heat and mass balance on a laboratory composting bioreactor operating on tomato plants residues. Wood shavings and municipal solid compost were used as a bulking agent and inoculums, respectively. The moisture content and C:N ratio were adjusted at $60 \%$ and $30: 1$, respectively. The temperature peaked after $31 \mathrm{~h}$ of operation reaching $63 .{ }^{\circ} \mathrm{C}$ and lasted for $9 \mathrm{~h}$. The result of the thermal analysis indicated that the average heat production value was $14.6 \mathrm{~kJ} / \mathrm{g}$ DM degraded. The conductive heat losses through the cylindrical body and the sidewalls of the bioreactor accounted for $62.6 \mathrm{~kJ}$. The moisture content stayed relatively constant $59.7 \pm 0.61 \%$. The reduction in volatile solids, total carbohydrate, fat and grease, protein , and TKN-N ( total Kjeldahl nitrogen) were 29.1, 31.7, 88.8, 17.8 and $11.0 \%$, respectively. The $\mathrm{NH}_{4}{ }^{+}-\mathrm{N}$ remained unchanged $(0.33-0.35 \%)$.

Ghaly et al (2006) reported on the bioreactor operated on an infected mixture of tomato plant residues, wood shavings, and municipal solid compost (1: $1.5: 0.28$ ). Tap water and urea were added to adjust the moisture content and C:N ratio to $60 \%$ and $30: 1$, respectively. Used cooking oil was added as a bioavailable carbon source to compensate for heat losses from the system and extend the thermophilic composting stage. The controlled thermophilic composting process was successful in destroying $B$. cinerea.

Hatem and Ghaly (1994) produced compost from municipal solid waste. The composting materials used in the study consisted of food wastes (30\%) grass clippings (30\%) leaves (30\%) and sawdust (10\%). Two aeration rates 0.85 and $1.70 \mathrm{~L} / \mathrm{min}$. $(0.0425$ and $0.0850 \mathrm{~kg} / \mathrm{min})$ were investigated. In all the experiments, the surface temperature of the compost material reached its maximum $\left(43-53^{\circ} \mathrm{C}\right.$ ) within 2 days from the start of the experiment, remained relatively constant for 4 days and then began to fall off back to the ambient temperature. Similar trends were observed for the temperature at the center of the compost mass. The process was considered complete when the surface temperature decreased to the room temperature. The moisture content was reduced from $83-89 \%$ to $72-76 \%$. The $\mathrm{pH}$ of the raw materials remained in the range of 8-9. However, increased the percentage of 
ammonium nitrogen, from $7-13 \%$ to $25-40 \%$ indicating that the organic nitrogen was converted to ammonium nitrogen. The final material had a dark brownish - black color with an earthy smell.

\section{OBJECTIVE}

The aim of this study was to investigate the effectiveness of aeration rate and mixing period on the compost quality and maturity; and to study the relation of temperature, aeration rate, mixing period and carbon dioxide $\left(\mathrm{CO}_{2}\right)$ emission during the composting process.

\section{EXPERIMENTAL APPARATUS}

The composting system shown in Figure 1 consisted of a frame, three bioreactors, aeration system and a data acquisition system. The frame was made of two parts. The main part was made of three aluminum sheets $(3.2 \mathrm{~mm}$ thick), the central one measured $330 \times 1100 \mathrm{~mm}$ and the two side sheets measured $140 \times 1100$ $\mathrm{mm}$ each. They were soldered together making a vertical channel (U shape) with a length of $1100 \mathrm{~mm}$, a width of $330 \mathrm{~mm}$ and a depth of $140 \mathrm{~mm}$. This $U$ shape stand held the mixing motors, flow meters, air and exhaust gas manifolds and tubing, and the thermocouple wires. The second part of the frame was a horizontal supporter made of three $50 \times 50 \mathrm{~mm}$ aluminum angles $3.2 \mathrm{~mm}$ thick, two of which measured 700 $\mathrm{mm}$, whereas the third one measured $328 \mathrm{~mm}$ and kept the other two angles $330 \mathrm{~mm}$ apart. The aluminum angles were permanently soldered together. Each bioreactor was constructed of $203 \mathrm{~mm}$ (ID) polyvinyl chloride (PVC) pipe. The length and the wall thickness of the tube were 520 and $5 \mathrm{~mm}$, respectively. They were horizontally fixed to the main frame. One end of the tube was covered with removable circular Plexiglas plate (for the cleaning purposes) of $203 \mathrm{~mm}$ diameter and $6 \mathrm{~mm}$ thickness. This plate was recessed and secured into the cylinder by means of six stainless steel screws ( 6 $\mathrm{mm})$. 


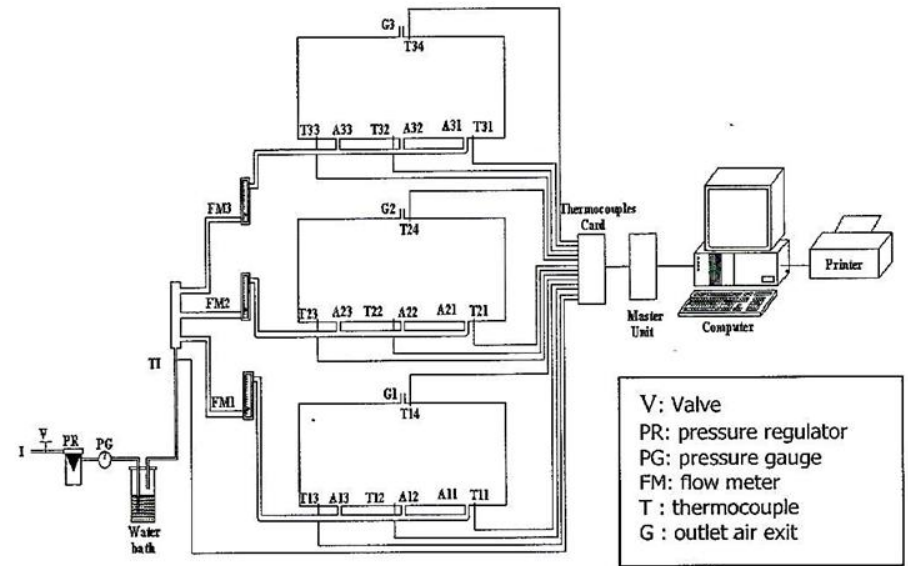

Fig.1. Bioreactors and the experimental setup

The fixed circular plate fitted into an aluminum ring, which was fastened into the frame by means of four bolts $(6 \mathrm{~mm})$ and nuts. There were three holes at the bottom and one at the top of the bioreactor, which were drilled and threaded to take a $12 \mathrm{~mm}$ nylon hose barb. The three holes at the bottom were connected to a manifold by $6.4 \mathrm{~mm}$ diameter Tygon tubing and used for aeration, whereas the fourth one at the top was used for the exhaust gas.

In order to maintain isothermal conditions, the bioreactors were insulated and continuously mixed. Both the removable and fixed circular plates were insulated with a $38.0 \mathrm{~mm}$ thick Styrofoam layer, while the tube was insulated with $38.0 \mathrm{~mm}$ thick fiberglass. The three bioreactors were fixed into the frame. A removable $10.0 \mathrm{~mm}$ diameter solid stainless steel shaft, having five stainless steel collars on the shaft in which five bolts of $69 \mathrm{~mm}$ in length and $6 \mathrm{~mm}$ diameter each, was mounted on two bearings. The shaft was rotated by a thermally protected electric motor (Model No. 127P1486/B, D.C., Sigma Instruments Inc., Braintree, MA, USA).

The air was supplied continuously to the bottom of the bioreactor from the laboratory air supply. It passed through a pressure regulator and a pressure gage (to maintain a pressure of about $5 \mathrm{kPa}$ ), then through a water bath (to humidify the inlet air to nearly $100 \%$ saturation) and finally through a flow meter (Model 32461-14, Cole-Parmer Instrument Company, Vernon Hills, IL, USA). The data acquisition unit consisted of a master unit, a thermocouple scanning card, software, temperature sensors, a personal computer and a printer. The master unit (Multiscan 1200, Omega, 
Stamford, CT, USA) was connected to a computer via RS 232 interface. The Thermocouple/Volt Scanning Card (MTC/24, Omega, Stamford, CT, USA) contained 24 isolated differential input channels. A window-based (Temp-view) software that featured a graphical spreadsheet-style user interface, allowed easy configurations of hardware and acquisition and display parameters. Four type T (copper-constantan) thermocouples (Cole Parmer, Chicago, IL, USA) were used for each bioreactor for temperature measurements. Three thermocouples were located at the bottom of the bioreactor and were used to measure the temperature of the compost mass. Whereas the fourth was located at the top of the bioreactor, near the outlet air exit (21 mm away) and was used to measure the temperature of the exhaust gas. Thermocouple locations, on the bottom of all bioreactors, were chosen to be far enough from the inlet air (65 mm away). An IBM personal computer (Pentium IV) and an HP (HewlettPackard) Laser Jet 4 printer was used. A simple computer program written by basic language was used to control the mixing period. The program was running by an IBM computer (under DOS, operating system) to turn on /of the mixer.

\section{MATERIALS}

The raw materials used in this study included food waste and saw dust. The food waste was obtained from the $\mathrm{O}^{\prime}$ Brain Hall Residence of Dalhousie University, Halifax, Nova Scotia, Canada. The food waste was shredded and packged then stored in the freezer at $-20{ }^{\circ} \mathrm{C}$. The saw dust obtained from a local lumber mill (Barrett lumber, Lower Sackville, Nova Scotia). Characteristics of these materials are shown in Table 1.

Table 1. Characteristics of raw materials food waste and sawdust.

\begin{tabular}{|c|c|c|}
\hline Characteristics & Food waste & Saw dust \\
\hline Moisture content $\%$ & 70 & 30 \\
\hline Dry matter & 0.2 & 0.7 \\
\hline $\mathrm{pH}$ & 4.5 & 7.6 \\
\hline Weight of $\mathrm{N}$ & 0.006 & 0.001 \\
\hline Weight of C $\quad(\mathrm{kg} / \mathrm{kg})$ & 0.09 & 0.4 \\
\hline Bulk Density $\quad\left(\mathrm{kg} / \mathrm{m}^{3}\right)$ & 620 & 198 \\
\hline Total P & 2.3 & 0.00 \\
\hline Total K & 3.5 & 0.4 \\
\hline
\end{tabular}

\section{EXPERIMENTAL PROCEDURE}

The temperature sensors (Thermocouples type $T$ ) were calibrated using ice and boiling water baths. The thermocouples including the fittings were immersed into the 
ice bath and hooked up to the data acquisition system individually. The thermocouple reading as temperature in degree centigrade was corrected to read zero ${ }^{\circ} \mathrm{C}$ (offset) and then into the boiling water to correct the upper limit. The calibration equation is a linear relationship as follows:

$$
T_{\text {corrected }}=a \times T_{\text {Actual }} \pm b
$$

where:

$$
\begin{array}{ll}
T_{\text {corrected }} & \text { is the corrected temperature reading, } \\
T_{\text {Actual }} & \text { actual temperature reading, } \\
a & \text { slope of the linear line, constant } \\
b & \text { intercept (offset), constant. }
\end{array}
$$

The amount of sawdust (S) added to each $\mathrm{kg}$ of food waste to adjust the C:N ratio at $30: 1$ and the moisture content at $60 \%$ was determined using the following formula ( Esther and Julie, 2001):-

$\mathrm{C}: \mathrm{N}=\mathrm{C}$ in waste $+\mathrm{C}$ in sawdust

$\mathrm{C}: \mathrm{N}=\frac{\mathrm{C} \text { in waste }+\mathrm{N} \text { in sawdust }}{\mathrm{N} \text { in }}$

$30=\frac{0.09+S(0.4)}{0.006+S(0.001)} ; \quad \mathrm{S}=0.25 \mathrm{Kg}$

A mixture of food waste and sawdust at a ratio of $4: 1$ a moisture content of $60 \%$ was prepared. $25 \mathrm{~kg}$ of the final mixture was mixed well and divided into $3.5 \mathrm{~kg}$ packages. One package was placed in each bioreactor which occupied $75 \%$ of the total volume of the bioreactor. Air flow rates of $0.075,0.1$ and $0.15 \mathrm{~m}^{3} / \mathrm{h}$ were used

\begin{tabular}{|c|c|c|c|c|c|}
\hline $\begin{array}{l}\text { Composting } \\
\text { mixture }\end{array}$ & $\begin{array}{l}\text { Aeration time } \\
\text { (h) }\end{array}$ & $\begin{array}{l}\text { Mixing speed } \\
\text { rpm }\end{array}$ & $\begin{array}{l}\text { Mixing time } \\
\text { (h) }\end{array}$ & $\begin{array}{c}\text { Aeration rate } \\
(\mathrm{m} 3 / \mathrm{h})\end{array}$ & $\begin{array}{c}\text { Bioreactors } \\
\text { and replicates }\end{array}$ \\
\hline \multirow{6}{*}{$\begin{array}{l}\text { Food wastes and } \\
\text { sawdust }\end{array}$} & \multirow{6}{*}{24} & \multirow{6}{*}{5} & \multirow{3}{*}{12} & 0.075 & $A_{1}$ \\
\hline & & & & 0.1 & $B_{1}$ \\
\hline & & & & 0.15 & $C_{1}$ \\
\hline & & & \multirow{3}{*}{24} & 0.075 & $A_{2}$ \\
\hline & & & & 0.1 & $\mathrm{~B}_{2}$ \\
\hline & & & & 0.15 & $C_{2}$ \\
\hline
\end{tabular}
during the experiment. A mixing speed of $5.0 \mathrm{rpm}$ was used in two different mixing periods 12 and $24 \mathrm{~h}$ as shown in Table 2. The temperature was continuously monitored during the study.

Table 2. The experiment design.

The $\mathrm{CO}_{2}$ was performed every day using a portable $\mathrm{CO}_{2}$ digital meter (Columbus Instruments Portable gas meter (PGM)). Total nitrogen (TKN), total carbon (TC), dry matter (DM), bulk density, $\mathrm{pH}$, total $\mathrm{P}$ and total $\mathrm{K}$ were performed on the initial and 
final samples. The moisture content (MC) and the dry matter were determined according to the On Farm Composting Hand Book (Rynk 1992 - NRAES- 54) by drying the samples at $105{ }^{\circ} \mathrm{C}$ for $24 \mathrm{~h}$ until the constant weight then the moisture was calculated using the following formula

$$
M C \%=\left(W_{w}-W_{d}\right) / W_{w}
$$

Where:

$$
\begin{array}{ll}
\text { MC\% } & \text { : Moisture content \% } \\
\mathrm{W}_{\mathrm{w}} & : \text { Wet weight }(\mathrm{g}) \\
\mathrm{W}_{\mathrm{d}} & : \text { Dry weight }(\mathrm{g})
\end{array}
$$

The dry matter was determined as the difference between total weight and weight of water in each sample.

The compost $\mathrm{pH}$ was measured using Fisher Accumet $\mathrm{pH}$ meter, $50 \mathrm{~cm}^{3}$ sample of compost material was diluted $1: 10$ (v:v) distilled - deionzed water and placed in the mechanical shaker at $230 \mathrm{rpm}$ for 30 minutes. For Total Kjeldahl Nitrogen (TKN) $1 \mathrm{gm}$ of the composted material was digested with $4 \mathrm{ml}$ concentrated sulphuric acid $\left(\mathrm{H}_{2} \mathrm{SO}_{4}\right)$ and $20 \mathrm{ml}$ distilled water, then placed in digester at $420{ }^{\circ} \mathrm{C}$ for $1 \mathrm{~h}$ under vacuumed ventilator and then titrated. The bulk density was determined by filling container of known volume and weight with the materials and the filled container was weighed. The bulk density equals the filled container weight minus the empty container weight divided by the container volume. Total carbon, dry matter and nutrients elements of the composted sample were determined at the Materials Engineering Center (MEC) of Dalhousie University. Elements were determined by flame atomic absorption spectrometer (Spectra AA 55B, Varian Australia Ply Ltd. Mulgrave, Victoria. Australia) with detection limit of $1 \mathrm{ppm}$ except Carbon dioxide and non-carbonate carbon were determined with Leco carbon analyzer (Model 516-000).

\section{RESULTS AND DISCUSSION}

\section{General properties}

Some chemical and physical properties of the initial mixture and the produced compost are presented in Table 3. The initial moisture content of the mixed materials was adjusted at $60 \%$ and the final moisture contents were in the range of $43 \%$ $54 \%$. 
Table 3. The General properties of the initial mixture and the final products from each bioreactor

\begin{tabular}{|l|l|l|l|l|l|l|l|l|}
\hline $\begin{array}{l}\text { Mixture and } \\
\text { bioreactors }\end{array}$ & $\begin{array}{c}\mathrm{MC} \\
(\%)\end{array}$ & $\begin{array}{c}\mathrm{DM} \\
(\mathrm{kg} / \mathrm{kg})\end{array}$ & $\mathrm{pH}$ & $\begin{array}{c}\mathrm{TKN} \\
(\mathrm{kg} / \mathrm{kg})\end{array}$ & $\begin{array}{c}\mathrm{T} . \mathrm{C} \\
(\mathrm{kg} / \mathrm{kg})\end{array}$ & $\begin{array}{c}\text { Bulk density } \\
\left(\mathrm{kg} / \mathrm{m}^{3}\right)\end{array}$ & $\begin{array}{c}\text { Total } \mathrm{P} \\
(\mathrm{g} / \mathrm{kg})\end{array}$ & $\begin{array}{c}\text { Total } \mathrm{K} \\
(\mathrm{g} / \mathrm{kg})\end{array}$ \\
\hline Initial mixture & 60 & 0.35 & 5.5 & 0.004 & 0.12 & 522 & 1.2 & 3.0 \\
\hline $\mathrm{A}_{1}$ & $54 \mathrm{a}$ & $0.3 \mathrm{a}$ & $8.6 \mathrm{a}$ & $0.005 \mathrm{~b}$ & $0.1 \mathrm{a}$ & $470 \mathrm{a}$ & $1.9 \mathrm{a}$ & $3.3 \mathrm{a}$ \\
\hline $\mathrm{B}_{1}$ & $50 \mathrm{~b}$ & $0.3 \mathrm{a}$ & $8.7 \mathrm{a}$ & $0.0075 \mathrm{~b}$ & $0.09 \mathrm{a}$ & $461 \mathrm{~b}$ & $2.0 \mathrm{a}$ & $3.3 \mathrm{a}$ \\
\hline $\mathrm{C}_{1}$ & $45 \mathrm{c}$ & $0.27 \mathrm{~b}$ & $8.7 \mathrm{a}$ & $0.006 \mathrm{~b}$ & $0.08 \mathrm{~b}$ & $424 \mathrm{c}$ & $2.1 \mathrm{a}$ & $3.5 \mathrm{a}$ \\
\hline $\mathrm{A}_{2}$ & $53 \mathrm{a}$ & $0.3 \mathrm{a}$ & $8.6 \mathrm{a}$ & $0.006 \mathrm{~b}$ & $0.1 \mathrm{a}$ & $468 \mathrm{~b}$ & $2.0 \mathrm{a}$ & $3.0 \mathrm{a}$ \\
\hline $\mathrm{B}_{2}$ & $46 \mathrm{c}$ & $0.28 \mathrm{~b}$ & $8.6 \mathrm{a}$ & $0.007 \mathrm{~b}$ & $0.09 \mathrm{a}$ & $445 \mathrm{~b}$ & $2.0 \mathrm{a}$ & $3.5 \mathrm{a}$ \\
\hline $\mathrm{C}_{2}$ & $43 \mathrm{c}$ & $0.27 \mathrm{~b}$ & $8.6 \mathrm{a}$ & $0.005 \mathrm{a}$ & $0.08 \mathrm{~b}$ & $420 \mathrm{c}$ & $2.0 \mathrm{a}$ & $3.5 \mathrm{a}$ \\
\hline
\end{tabular}

$A_{1}, B_{4} C_{1}:$ The compost produced from $12 \mathrm{~h}$ mixing period and aeration rates $0.75,0.1$, and

$0.15 \mathrm{~m}^{3} / \mathrm{h}$ respectively.

$A_{2}, B_{2}, C_{2}:$ The compost produced from 24h mixing period and aeration rates $0.75,0.1$, and

$0.15 \mathrm{~m}^{3} / \mathrm{h}$ respectively.

Means within a group followed by the same letters were not significantly different at probability 0.05 using Duncan test (SAS ver.5, 1985).

The moisture of the compost materials provides an environment rich in dissolved nutrients essential for microbial degradation activities. Changes were observed in the moisture content of the materials due to the water lost with exhaust gas. Richard et al (2002) reported that the optimum moisture content of the initial composting mixtures varies from 50 to $70 \%$. Laing et al (2003) found $50 \%$ moisture content seems to be the minimum requirement for rapid increase in microbial activity, while 60 to $70 \%$ provided maximum activities during the composting process. The authors also stated that decreasing the initial moisture content found at the end of the composting process. The results also showed that the amounts of moisture lost after the composting process depends on the aeration rate and mixing period. A positive relationship was found between loss of moisture and increase of aeration rate and/or mixing period. Franke (1997) stated that decreasing moisture content during the composting depended on the aeration rate and the microbial activity. Kulcu and Yaldiz (2004) stated that with different aeration rates the moisture contents of all samples were decreased continuously during composting. By the end of the compost process the moisture contents were declined from $71 \%$ to 65,64 , and $57 \%$ at aeration rates $0.1,0.21$, and $0.41 \mathrm{~L} / \mathrm{min} / \mathrm{kg}$, respectively.

The dry matter decreased at the end of the composting process related to the microbial activity. The total dry matter loss was in the range of $14-22 \%$ depending on the aeration rate and the mixing period. The results showed that with increasing of 
the aeration rate and/or mixing period the dry matter loss increased. The maximum dry matter loss was found with aeration rate $0.15 \mathrm{~m}^{3} / \mathrm{h}$ and at all the mixing period. Rajbanshi and Inubushi (1998) reported that the total dry matter loss was $157 \mathrm{mg} / \mathrm{g}$ and $120 \mathrm{mg} / \mathrm{g}$ after the composting operation depending on the microbial activities. Kulcu and Yaldiz (2004) stated that the higher dry and organic matter lost were observed in the reactor had the higher aeration rate and the decrease was more pronounced during the first stages of the process.

The $\mathrm{pH}$ levels of the compost materials varied during the composition process. The final $\mathrm{pH}$ increased from 5.5 to approximately $8.5-8.7$. The results showed no significant effect of the aeration rate or the mixing period on the $\mathrm{pH}$ values. Balitas (1992) found alkaline $\mathrm{pH}$ values in composts made from wastes and olive tree leaves. Rajbanshi and Inubushi (1998) reported that during the microbial decomposition of "ant materials, decarboxylation of organic anions results in a $\mathrm{pH}$ rise. Kulcu and Yaldiz (2014) stated that with different aeration rates there were no significant differences between the $\mathrm{pH}$ values during and at the end of the composting process, the final $\mathrm{pH}$ values were in the range of $8.5-8.8$.

Increasing in total nitrogen was observed with all treatments. The higher value of TKN was noticed in the compost produced from aeration rate $0.1 \mathrm{~m}^{3} / \mathrm{h}$ and $12 \mathrm{~h}$ mixing period. $\mathrm{NH}_{3}$ smell was noticed during the experiment that is due to loss of $\mathrm{NH}_{3}$ $\mathrm{N}$ with exhaust gas, this explain why the TKN did not have a proportional increase with the aeration rate in this study. Franke (1997) proposed that the $\mathrm{NH}_{3}$ emission increased with the composting time. The higher release of $\mathrm{NH}_{3}$ gas noticed during peck temperature and with the higher aeration rate. Rajbanshi and Inubushi (1998) reported that unproportional loss of different elements of the organic matter seems to be the reason for the increase in the nitrogen concentration during the composting process. Kulcu and Yaldiz (2004) found that increasing the aeration rate from $0.1 \mathrm{~L} / \mathrm{min}$ to $0.4 \mathrm{~L} / \mathrm{min}$ increased the concentration of total nitrogen from 3.4 to $3.9 \mathrm{mg} / \mathrm{g}$ but with increasing the aeration rate to $0.8 \mathrm{~L} / \mathrm{min}$. the TKN reduced to $3.4 \mathrm{mg} / \mathrm{g}$.

The percent reduction of the total carbon ranged from 16 to $33 \%$ depending on the aeration rate. The high reduction percents were found with the high aeration rate $0.15 \mathrm{~m}^{3} / \mathrm{h}$ while the mixing period effectiveness was regardless. Kulcu and Yaldiz (2004) found the same results at different aeration rates. However the reduction amounts in the total carbon generally was low in this experiment (reduced from 0.12 to 0.08 ) maybe due to the fact that most of the carbon in sawdust was not bioavailable source for microbes. Back - Friis et al (2001) achieved total carbon reduction of $65 \%$ after 31 days and $68 \%$ after 22 days of composting crop and food 
waste. Wang, et al. (2003) observed reduction of organic carbon of $14 \%$ during 12 days of composting of sewage sludge and vegetable wastes.

The bulk density of the mixture compost materials were declined in all the final compost samples. The results indicated that the bulk density decreased by a percent ranged from $10 \%$ to $20 \%$ depending of the aeration rate and mixing period. The results indicated that by increasing the aeration arte and mixing period the reduction in bulk density increased due to the reduction of the moisture content during the composting process. Esther and Julie (2001) found that the bulk density of the compost materials decreased from 452 to $412 \mathrm{~kg} / \mathrm{m}^{3}$ with the composting time. Suzelle et al (2002) reported that there was a decrease in the bulk density of the mixture compost materials ranging from 40 to $55 \%$ at the end of the compost processes depending on the air flow rates.

The quantity of the nutrients (total phosphorus and total potassium) is important in the mixture wastes for microorganism's growth as well as in the final product as an indicator for the quality of compost. The initial amount of the total phosphate and the total potassium were studied during this experiment and it was found to be sufficient for the microbial growth according to Manios (2004) who suggested nutrients concentration in the mixture waste not less than $0.4 \mathrm{mg} / \mathrm{g}$. At the end of the experiment the concentration of the total phosphate was increased from 1.2 to 1.9 and $2.0 \mathrm{~g} / \mathrm{kg}$ as well the total potassium increased from 3.0 to 3.3 and 3.5 $\mathrm{g} / \mathrm{kg}$. Manios (2004) stated that nutrients concentrations in the compost mixture especially agriculture based, is concerned with the suitability of utilization of the final product as a plant nutrients.

\section{Temperature and carbon dioxide}

The average temperature profiles during the composting process are presented in figure 2. The maximum temperature ranged from 48 to $52{ }^{\circ} \mathrm{C}$ depending on the aeration rate and mixing speed. The temperature started to increase inside the bioreactors by the third or fourth day. Temperatures higher than $40^{\circ} \mathrm{C}$ were observed in all bioreactors after one week and remained for $5-6$ days. The maximum temperature that was higher than $50{ }^{\circ} \mathrm{C}$ was found only in bioreactors $C_{1}$ and $C_{2}$ and was maintained for three days. Liang et al. (2003) stated that temperature has been shown to be a critical determinant of composting efficiency. The temperature range for optimal composting is between 52 and $60^{\circ} \mathrm{C}$. 


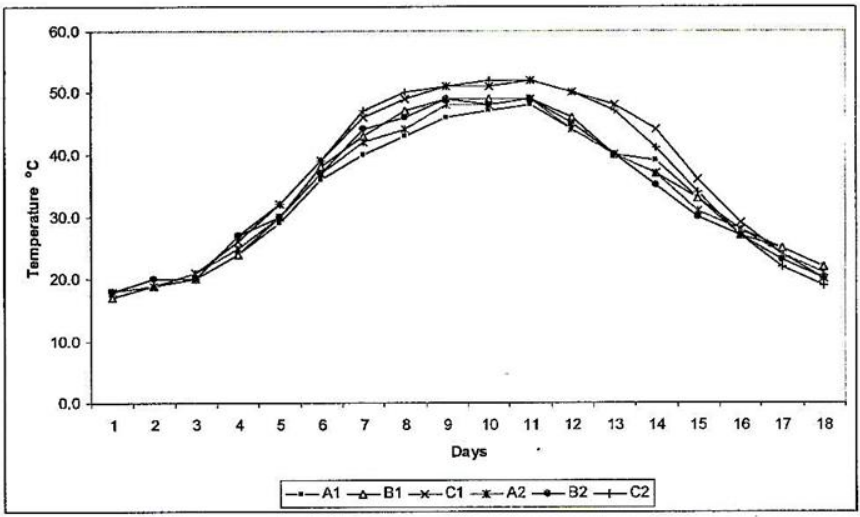

Fig. 2. Temperatures during the composting process

Kulcu and Yalidiz (2004) reported that the composting process reached the temperature of $50^{\circ} \mathrm{C}$ after the first week. However in this experiment there was a proportional relation between the temperature and the aeration rate. On the other hand there was no effect for the mixing period when the aeration rate was at 0.15 $\mathrm{m}^{3} / \mathrm{h}$. Hatem and Ghaly (1994) reported that the highest surface temperatures in the composting process were observed with increased aeration rates that due to higher aeration rates promoted maximum microbial growth. Kulcu and Yaldiz (2004) stated that using a different aeration rate a significant difference in temperature regime was found among all composting reactors after the second week. After 11 days from starting the composting process the temperatures gradually decreased. The possible reason for this decrease is because of the decrease in bioavailable carbon and nitrogen sources for the microorganisms activities. Esther and Julie (2001) reported that temperature remain high for one week or more before decreasing. The maximum temperatures should not exceed $66^{\circ} \mathrm{C}$ otherwise microbial activity will diminish due to spore formation.

\section{Carbon dioxide (CO2)}

The $\mathrm{CO}_{2}$ production in the composting process was due to the mineralization of the organic matter. Figure 3 . shows the relation between the composting times and the $\mathrm{CO}_{2}$ emissions at different aeration rates and mixing period. In all reactors the $\mathrm{CO}_{2}$ emission increased and proportional with temperatures and aeration rates due to the following equation( Alkoaik, 2004):-

$$
\mathrm{C}_{x} \mathrm{H}_{y} \mathrm{O}_{z}+\mathrm{O}_{2} \stackrel{\text { Microbes }}{\longrightarrow} \mathrm{CO}_{2}+\mathrm{H}_{2} \mathrm{O}+\text { heat }
$$




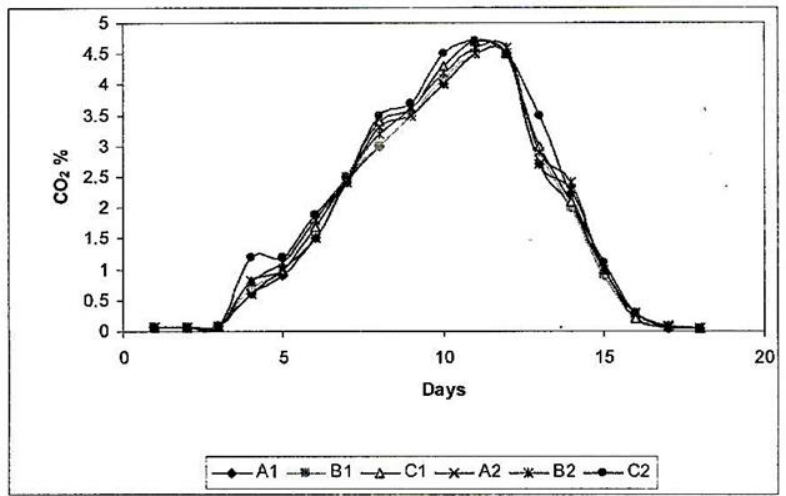

Fig. 3. $\mathrm{CO}_{2}$ emissions during the composting process

Verdonck et al. (1984) reported that in the composting process when the temperature is high; a large amount of $\mathrm{CO}_{2}$ is produced due to the intense microbiological activity. The maximum $\mathrm{CO}_{2}$ output were found at the temperatures ranging from 55 to $60^{\circ} \mathrm{C}$. Manios et al. (2006) stated that carbon availability and temperature profile of the composting process has a significant effect on the production of $\mathrm{CO}_{2}$. The results indicated that $\mathrm{CO}_{2}$ emission was increased after three days and decreased after thirteen days with all aeration rates and mixing periods. Kulcu and Yaldiz (2004) stated that $\mathrm{CO}_{2}$ rate increased in all bioreactors depending on microorganism activity and aeration rate. The authers also stated that the $\mathrm{CO}_{2}$ rate was increased after four days and decreased after ten days in all the aerated bioreactors.

The relation between the temperatures, the accumulation emissions of carbon dioxide, the aeration rates and the mixing period in this study could be simulated by an equation which was investigated using the regressions analysis by (Minitab, 14.20 LEAD technologies 2004).

$$
T=20+6.5 \mathrm{CO}_{2}+24 \mathrm{~A}-0.01 \mathrm{M}
$$

Where: -
$\mathrm{T:} \quad$ is the compost temperature $\left({ }^{\circ} \mathrm{C}\right)$
A: the aeration rate $\left(\mathrm{m}^{3} / \mathrm{h}\right)$
M: $\quad$ mixing period $(h)$
$\mathrm{CO}_{2}: \quad$ emission of carbon dioxide (\%) 


\section{CONCLUSIONS}

A composting system consisting of three bioreactors was used to produce compost from food waste. According to the results the general properties which included, moisture content, dry matter, $\mathrm{pH}$, total Kjeldahl nitrogen, total carbon, bulk density, total phosphate and total potassium were changed at the end of the composting process and the changes depended on both the aeration rates and mixing period. The temperatures and $\mathrm{CO}_{2}$ were in a proportional relation in all the bioreactors. A treatment combination of an aeration rate $0.15 \mathrm{~m}^{3} / \mathrm{h}$ and $\mathrm{a} 12 \mathrm{~h}$ mixing period produced a good quality compost in 18 days and as well as saving $50 \%$ of the power consumed in the mixing operation compared with the continueous mixing. The general properties of the compost produced from this treatment were; $45 \%, 0.27$ $\mathrm{kg} / \mathrm{kg}, 8.7,0.006 \mathrm{~kg} / \mathrm{kg}, 0.08 \mathrm{~kg} / \mathrm{kg}, 424 \mathrm{~kg} / \mathrm{m}^{3}, 2.1 \mathrm{~g} / \mathrm{kg}$ and $3.5 \mathrm{~g} / \mathrm{kg}$ for moisture content, dry matter, $\mathrm{pH}, \mathrm{TKN}, \mathrm{TC}$, Bulk density, $\mathrm{P}$ and $\mathrm{K}$ respectively.

\section{ACKNOWLEDGMENTS}

The Biological Engineering Department, Dalhousie University, Halifax Nova Scotia, Funded this study; I thank all the staff of the Biological Engineering Department for their efforts.

\section{REFERENCES}

1. Alkoaik, F. 2004. Fat of plant pathogens and pesticides during composting of greenhouse tomato plant residues. Ph.D. Thesis, Dalhousie university, Halifax NS, Canada.

2. Alkoaik, A. and A. E. Ghaly. 2006. Determination of heat generated by metabolic activities during composting of greenhouse tomato plant residues. NRC research, Canada February 2006.

3. Balitas, M. L. 1992. Life inside a compost heap. Organic Gardening magazine.

4. Beck-Friis, B., S. Smars, H. Jonsson and H. Kirchman, 2001. Gaseous emission of carbon dioxide, ammonia, nitrous oxide from organic household waste in a compost reactor under different temperature regimes. Journal of Agricultural Engineering Research. 78(4):423-430.

5. Esther, B. and B. Julie. 2001. Design and implementation a composting system for a community food bank and garden. Agricultural and bio systems engineering, A technical report, McGill University, Canada

6. Franke, J. O. 1997. Cold climate composting, the influence of sub zero ambient and ventilating temperature. M. Sc. Edmonton University, Alberta, Canada. 
7. Ghaly, A.E., F. Alikoaik and A. Sanow. 2006. Inactivation of botrytis cinerea during thermophilic composting of greenhouse tomato plant residues. Applied biochemistry and biotechnology. 133(1): $59-75$.

8. Hatem, M. H. and A. E. Ghaly. 1994. Composting of municipal solid waste. Misr Journal of Agricultural Engineering. 11(2): 547-558.

9. Kulcu, R. and Yaldiz. 2004. Determination of aeration rate and kinetic of composting some agricultural waste. Bioresource Technology. 93(1): 49-57.

10. Liang, C. K., C. Das and R. W. McClendon. 2003. The influence of temperature and moisture contents regimes on the aerobic microbial activity of a biosolids composting blend. Bioresource Technology. 86(1): 131-137.

11. Manios, T. 2004. The composting potential of different organic solid wastes. Environmental international. 29 (8):1079-1089.

12. Manios, T. K. et al. 2006. Methane and carbon dioxide emission in a two-phase olive oil mill sludge windrow pile during composting, Waste Management, Research1. 10(2): 191- 199.

13. Polprasert, C., N. Kongsricharoern and W. Kanjanaprapin. 1994. Production of feed and fertilizer from water hyacinth plants in the tropics. Waste Management Research. 12(1): 3-11.

14. Rajbanshi, S. S. and K. Inubushi. 1998. Chemical and biochemical changes during laboratory- scale composting of allopathic plant leaves. Biofertile Soils. 26(1): 6671.

15. Richared, T. L., H. V. Hamelers, A. H. Veeken and T. Silva. 2002. Moisture content relation ships in composting processes. Composting Science and Utilization. 10(4): 286-302.

16. Rynk, P. 1992. On farm composting hand book, Northeast Regional Agricultural Engineering Service (NRAES- 54), Ithaca, N.Y. USA.

17. Suzelle, B., c. Denis, T. Maherwd and K. William. 2002. Compost air flow resistance. Biosystems engineering. 81(4):433-441.

18. Verdonck, O., M. Boodt, P. Stradiot and R. Penninck. 1984. The use of tree bark and tobacco waste in agricultural and horticulture. Elsevier applied science publishers. NY, 10017, USA. ISBN: 0853343578: 203 - 215.

19. Wang, J. Y., O. Stabnikova, S. T. L. Tay, V. Ivanov and J. H. Tay. 2003. Intensive composting of sewage sludge and food waste by Bacillus thermoamylovorans. World Journal of Microbiology and Biotechnology. 19(1): 427-432. 
تأثير معدلات التهوية وزمن التقليب على كمبوست مخلفات الأطعمة

\section{هشام عبد المنعم فرج}

معثز بحوث الهندسة الزراعية - مركز البدوث الزراعية - الدقى - جيزة

تم الستخدام خليط من مخلفات الطعام مع نشارة الخشب لإنتاج كمبوست باستخدام مخمر حيوي

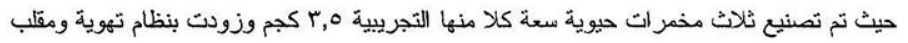
دالخلي إضافة إلي أربعة مجسات حر ارية من النوع (T, thermocouples) لكل مخمر منصلة بنظلام رقمي لنسجيل وتخزين البيانات على الحاسب الآلي على مدار اليوم وذللك بمعل الهندسة الحيوية

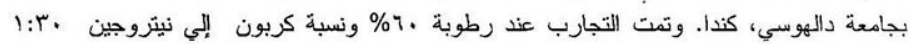

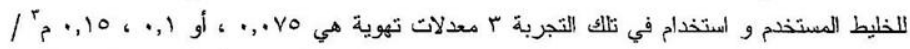

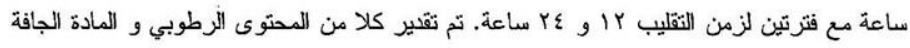

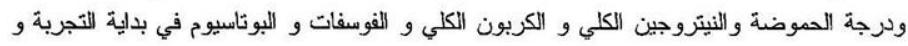

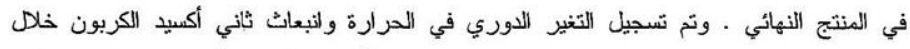

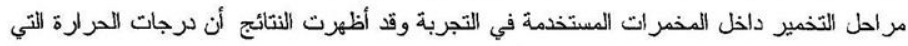

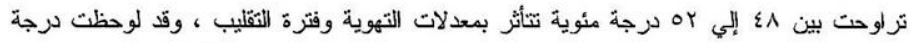

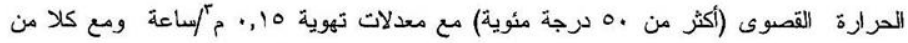

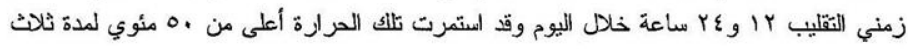

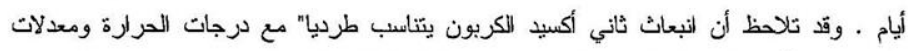

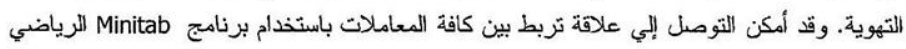

\section{$\left(T=20+6.5 \mathrm{CO}_{2}+24 \mathrm{~A}-0.01 \mathrm{M}\right)$}

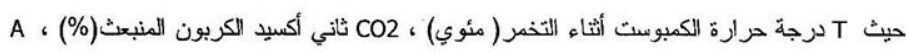

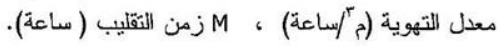

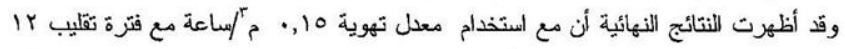

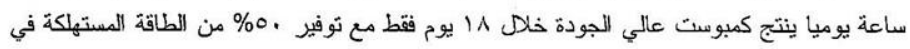
عملية النقليب. 